\title{
Communism and Toronto Schools: Contention and Politics in the Toronto School Board, 1941-1962.
}

\author{
Stephanie Weber
}

In the decades following World War II, the Toronto School Board was influenced by the Cold War anti-communist fear that permeated political, religious, and educational discourse in Canada. Despite this ideological climate, communists were able to hold positions on the board and enact policies that affected schools. Communists on the Board exercised a certain degree of influence in the Board's decision making and continued to be a voice of opposition to increasingly anti-communist members until 1951.

The politics of the Toronto School Board occurred within a larger context of anticommunist anxiety related to education. Throughout the 1940s and into the early 1950s, The Globe and Mail covered its policies and campaigns through an often anti-communist lens, reflecting the increasingly hostile public opinion towards communists in Toronto's government and public life. In March 1948, an article in The Globe and Mail reported that Catholic leaders did not feel the public school system was doing enough to "combat" communism. In the eyes of the article's author, however, "Marxist teaching" was equally opposed to Protestantism and Catholicism, and that Protestants had "quite as much to lose" as Catholics if the influence of communism widened. The article ended by admitting that Ontario schools had largely emphasized "British tradition" and democratic government for many years, and that teachers were already "carefully chosen" based on "their qualities of character and teaching ability." ${ }^{1}$ This status quo was apparently insufficiently anticommunist for Catholic leaders and, the author implies, Protestants, too, should be alarmed about the threat of Communist influence, if not its present reality.

\footnotetext{
1 "Rule Should Apply Equally," The Globe and Mail, March 1, 1948, Proquest Historical Newspapers, The Globe and Mail (1936-Current)
} 
As historian Paula Maurutto explains, there was a huge increase postwar anticommunist anxiety among Catholic clergymen in Toronto. This was in part fuelled by large numbers of Catholic immigrants to Toronto. These immigrants were poor, so Catholics feared they would sympathize with communism. ${ }^{2}$ The Catholic Church was afraid of communist influence, and sought to suppress communism, because the Communist Party of Canada was vocally anti-religion. ${ }^{3}$ As a result, Catholics worked with anti-communist organizations like the Toronto Red Squad to police communist influence within the Catholic Archdiocese of Toronto and affiliated societies. Here, anti-communist anxiety manifested in an extra-governmental form of policing.

Catholics were not the only group anxious about communism in schools, and other examples of contention between Toronto's schools and communism can be found in The Globe and Mail. An article published in April 1948 describes a hearing of Dr. James D. Endicott, a Canadian communist sympathizer, concerning Toronto's Central Technical School's movement to deny school property use for communist organizations. The Civil Rights Union had condemned this act, and the article quotes Endicott as saying it was "an act of political discrimination and an unnecessary interference with the political rights of the citizens of Toronto." Endicott suggested that the right to freely express political ideas is important, and deplored "red-baiting."” The article then describes the hearing without opining upon its outcome or involved parties.

An article published in November 1950, however, entitled "Bar Any New Teachers for Communist Taint," suggests a spike in anti-communist anxieties. It reports new municipal legislation that teacher applicants would be "screened for Communist sympathies" with background checks for affiliation with communist organizations prior to employment by Toronto's Board of Education. ${ }^{5}$ The two Communist trustees on the board

\footnotetext{
2 Paula Maurutto, "Private Policing and Surveillance of Catholics: Anti-communism in the Roman Catholic Archdiocese of Toronto, 1920-1960," Labour/Le Travail 40 (Fall 1997): 113-36.

3 Ibid.

4 “Endicott Deplores 'Red-Baiting,' Raps School Board," The Globe and Mail, April 23 1948, Proquest Historical Newspapers, The Globe and Mail (1936-Current).

5 "Bar Any New Teachers For Communist Taint," The Globe and Mail November 17 1950, Proquest Historical Newspapers, The Globe and Mail (1936-Current).
} 
called the bill a "witch hunt" and "pleaded vigorously and eloquently" against the proposal before it was voted in. 6

In the early years of the Cold War, the Toronto School Board was fraught with contention, particularly during the elections for new trustees. In 1948, candidate Harold Menzies urged voters to "keep communism out of our schools." ${ }^{7}$ His platform was based on the goal of protecting children's future from the danger of communism, and he called himself the "only candidate not a communist" in his campaign blotter. ${ }^{8}$ Menzies, historian Frank K. Clarke notes, had been on the School Board as a trustee twice previously, as well as as Chair in 1941, but his reason for running again in 1944 and then in 1948 was to keep young people from being "subjected to communism's doctrines." 9 This was likely a response to the escalating Cold War tensions and the continued visibility of communists on the school board. Menzies made his anti-communism clear, saying that it was "inadvisable" to have communists on the board, in order to keep children away from the "poison" of communism that "denies moral and spiritual value." 10

While Harold Menzies was running his campaign against the "menace" of communism, however, and into the 1950s, communists continued to serve on the board. Edna Ryerson and Sam Walsh had served on the board for years before Walsh was "trounced" (in the words of The Globe and Mail) in the 1950 election by Percy Might.11 Edna Ryerson vocally opposed Menzies' motion to make communist gatherings on school property illegal, naming people's "fear and cowardice" towards communism and their use of "methods of suppression" towards ideas they opposed, while the other opposition to Menzies' campaign pointed to the lack of evidence that Communists posed a threat toward Toronto's schools. ${ }^{12}$ Seemingly, Ryerson had significant influence on the press's initial reaction to Menzies' motions, which was mostly negative, arguing that the idea flouted

\footnotetext{
6 Ibid.

${ }^{7}$ Frank K. Clarke, "'Keep Communism Out of Our Schools': Cold War Anti-Communism at the Toronto Board of Education, 1948-1951." Labour/Le Travail 49 (Spring 2002): 93.

8 Ibid.

9 Ibid, 94.

10 Ibid, 95.

11 "Lone Communist In Civic Office Is Mrs. Ryerson," The Globe and Mail, December 5 1950, Proquest Historical Newspapers, The Globe and Mail (1936-Current).

${ }^{12}$ Clarke, "'Keep Communism Out of Our Schools,'” 96.
} 
democracy. ${ }^{13}$ These protests did not do enough to oppose the motion, and Menzies' motion passed, sending, in Clarke's view, "a clear message that an anti-Communist, prodemocratic consensus would prevail in the schools, even at the risk of infringing upon individual rights."14

During her time on the school board, Edna Ryerson's support or opposition to several motions set her apart from the non-communist board members. One example, which Clarke describes, was the issue of the introduction of textbooks teaching about communism to the Toronto school system. The books This Was My Choice by Igor Gouzenko and Spirit of Canadian Democracy by Margaret Fairley represented vastly different views of communism and the Cold War. Gouzenko's autobiography emphasized the terror of communism and a warned about the danger posed by Canadian communists. Fairley's edited collection was made up of speeches and writings, unaccompanied by any of her own commentary, from democratic as well as Communist Canadians to present varied examples of political opinion. ${ }^{15}$ The Toronto School Board, as well as Director of Education Dr. C.C. Goldring, recommended Gouzenko's book. Goldring stated that Fairley’s book was “less suited" to teaching the concept and necessity of democracy. ${ }^{16}$ Ryerson, however, called Gouzenko a traitor to his country and felt that the book would "raise a generation of young Gouzenkos" in Canada. Fairley, as well as other critics, thought the board's vote was unfair, undemocratic, and verging on propaganda. ${ }^{17}$ Despite this, the Finance Committee approved the funds to purchase copies of Gouzenko's book for Toronto's schools while Ryerson and Walsh attacked the motion. ${ }^{18}$

Ryerson was also involved in postwar child care debates while serving on the board. In the postwar era, working-class women pushed for continued government-funded childcare. Canada's politicians were split between the postwar need of mothers for support and the inability to fund these public programs. The day care movement in Toronto continued from 1946 until 1951, with communist parties and political figures preventing

\footnotetext{
13 Ibid, 98.

${ }^{14}$ Clarke, "'Keep Communism Out of Our Schools,"' 100.

15 Ibid, 106.

16 Ibid, 107.

17 Ibid, 108.

18 Ibid.
} 
daycares from closing after the war. ${ }^{19}$ Edna Ryerson supported the Day Nurses and Day Care Parents, as did communist aldermen and trustees, and together these organizations struggled to preserve existing services. ${ }^{20}$ Ryerson was also a vocal advocate for hot lunches and free milk while the Board of Education opposed this, since the Education Act did not support non-academic funding. ${ }^{21}$ Despite the increasing red baiting during this time, Ryerson continued to advocate for women's groups along with Communist Party trustee Elizabeth Morton, on the basis that childcare was necessary in order to prevent juvenile delinquency. ${ }^{22}$ Communist support for women's groups led to an association of childcare itself with communism, and a general decrease in support for funding of day care. In 1951, Edna Ryerson was the only remaining communist left on the Board, and communist aldermen were now absent from City Council. ${ }^{23}$ The government implemented strict eligibility requirements for childcare, and the daycare movement was defeated by late $1951 . .^{24}$

Another issue plaguing the Toronto School Board was the policing of teachers' political leanings. Goldring defended Toronto schools from criticisms by the War Veterans Association, who questioned the loyalty of the Toronto School Board and its commitment to democracy, and asked whether enough democratic ideals were taught in Toronto's schools. Goldring responded to the WVA emphasizing the importance of Canada's government in curriculum, the preference given to Canadian books, and the fact that teachers were carefully screened, ${ }^{25}$ but he assured the Association that he would deal with complaints that teachers had been hired with previous involvement in the Communist party. ${ }^{26}$ However, there was criticism of the WVA's letter, both by the Globe and Mail and by the public, who thought it unnecessary to question loyalty since Toronto classrooms already stressed patriotism. As well, the Board would be on shaky legal ground to question

\footnotetext{
${ }^{19}$ Susan Prentice, “Workers, Mothers, Reds: Toronto's Postwar Daycare Fight," Studies in Political Economy 30, (Autumn 1989): 115.

20 Ibid.

${ }^{21}$ Ibid, 126.

22 Ibid.

23 Ibid, 130.

24 Ibid, 133.

${ }^{25}$ Clarke, "'Keep Communism Out of Our Schools,'” 103.

26 Ibid.
} 
teacher's political leanings as long as communism was not being taught in the classroom. ${ }^{27}$ Ryerson obviously opposed the Association's letter, but supporters thought it reasonable, and some of the ideas were embraced and adopted — such as the teaching of the dangers of police states. ${ }^{28}$ Edna Ryerson's criticism was dismissed since her husband was a high school teacher, and George Ewing, the committee's secretary, argued that she should "not be able to discuss matters which might possibly benefit her husband." 29 Ryerson was thus shut out of the discussion without the board having to rally against her for her communism.

According to Susan Prentice, by 1951, a "fiercely anti-communist climate prevailed," and red-baiting served to silence and discredit political opposition. ${ }^{30}$ It was for this reason that people were so reluctant to support Ryerson's endeavours, and this loss in support is also reflected by The Globe and Mail's coverage of the Toronto School Board trustee elections. Ryerson and Walsh's efforts to portray themselves as "progressives and allies of the working class" worked for much of the late 1940s, allowing them to keep their seats. ${ }^{31}$

Looking at The Globe and Mail's coverage of the Toronto School Board elections in the 1950s, however, waning support for communism and for Edna Ryerson is evident. An article from December 1950 proclaimed that the "Lone Communist in Civic Office Is Mrs. Ryerson" for 1951, and that Sam Walsh had been voted off. ${ }^{32}$ Two days later, the article "School Board Strengthened" covered the same event again, noting that Walsh had been "ousted" and that a "similar effort" was made against Edna Ryerson, one which "failed by a small margin" but had a good chance of ousting her the next year. ${ }^{33}$ The article suggested that her following was "crumbling," as she was down by 3,000 votes from her previous win, and that although she had a "clever mind," she was "handicapped by a typical Communist lack of respect for facts" which "seriously limits her value as a public servant." This article also mentioned that Harold Menzies had "benefitted considerably" from anti-Communism that year. The December 1953 article covering the Board election provided a small

\footnotetext{
${ }^{27}$ Ibid, 104.

${ }^{28}$ Ibid, 105.

${ }^{29}$ Ibid, 111.

30 Prentice, "Workers, Mothers, Reds," 130, 131.

31 Clarke, "Keep Communism Out of Our Schools,"” 110.

32 "Lone Communist In Civic Office Is Mrs. Ryerson," The Globe and Mail.

33 "School Board Strengthened," The Globe and Mail December 7 1950, Proquest Historical Newspapers, The Globe and Mail (1936-Current).
} 
biography of each candidate for each ward that year, giving suggestions to the reader in the description of each communist candidate about how to strategically vote so that these trustees did not win. ${ }^{34}$ This article supported Menzies and Nellie Tennant against Ryerson in one of the wards, suggesting that the voters support Menzies and Tennant in order to "retire Mrs. Ryerson to the obscurity which has overtaken other Communists formerly in Civic politics." ${ }^{35}$ In a 1962 article which gives short biographies of trustee candidates, there is no mention at all of communist affiliations. ${ }^{36}$ It appears that newspaper coverage was increasingly biased against communists, and against Ryerson, during the postwar period, which served to reinforce anti-communism in Toronto's public sphere.

One can situate the politics and anti-communism of the Toronto School Board in the larger context of communist fearing postwar Canada. Despite the common fear and anxiety surrounding communist influence on education, and by extension children, trustees such as Edna Ryerson were still able to hold positions on the board and oppose anti-communist bills before they were entirely voted off the board by 1951. The Globe and Mail's coverage of the Toronto School Board is a clear indicator of increasing public hostility towards communism in the education system, and reflects the larger anxieties governing people's fear and distrust of communism's influence on teachers and children in schools.

\footnotetext{
34 "The Toronto Board of Education," The Globe and Mail December 3 1953, Proquest Historical Newspapers, The Globe and Mail (1936-Current).

35 Ibid.

36 "Six Trustees Acclaimed, 24 Candidates Contest 12 Other Seats on Toronto Board of Education," The Globe and Mail November 28 1962, Proquest Historical Newspapers, The Globe and Mail (1936-Current).
} 
Works Cited

"Bar Any New Teachers For Communist Taint," The Globe and Mail November 17 1950, Proquest Historical Newspapers, The Globe and Mail (1936-Current).

Clarke, Frank K. "'Keep Communism Out of Our Schools': Cold War Anti-Communism at the Toronto Board of Education, 1948-1951." Labour/Le Travail 49 (Spring 2002): 93-119

“Endicott Deplores 'Red-Baiting,' Raps School Board," The Globe and Mail, April 23 1948, Proquest Historical Newspapers, The Globe and Mail (1936-Current).

"Lone Communist In Civic Office Is Mrs. Ryerson," The Globe and Mail, December 5 1950, Proquest Historical Newspapers, The Globe and Mail (1936-Current).

Maurutto, Paula. "Private Policing and Surveillance of Catholics: Anti-communism in the Roman Catholic Archdiocese of Toronto, 1920-1960," Labour/Le Travail 40 (Fall 1997): 113-36.

Prentice, Susan. “Workers, Mothers, Reds: Toronto’s Postwar Daycare Fight.” Studies in Political Economy 30 (Autumn 1989): 115-141

"Rule Should Apply Equally," The Globe and Mail, March 1, 1948, Proquest Historical Newspapers, The Globe and Mail (1936-Current)

"School Board Strengthened," The Globe and Mail December 7 1950, Proquest Historical Newspapers, The Globe and Mail (1936-Current).

"Six Trustees Acclaimed, 24 Candidates Contest 12 Other Seats on Toronto Board of Education," The Globe and Mail November 28 1962, Proquest Historical Newspapers, The Globe and Mail (1936-Current). 